\title{
A melanoma malignum korai felismerését befolyásoló tényezők
}

\author{
Petrovszki Irén oh. ${ }^{1}$ - Csányi Ildikó dr. ${ }^{1}$ - Szücs Mónika ${ }^{2}$ \\ Ócsai Henriette dr. ${ }^{1,3}$. Houshmand Nazanin dr. ${ }^{1}$ - Kemény Lajos dr. ${ }^{1,4}$ \\ Oláh Judit dr. ${ }^{1}$ - Baltás Eszter dr. ${ }^{1}$
}

\author{
Szegedi Tudományegyetem, Általános Orvostudományi Kar, ${ }^{1}$ Bőrgyógyászati és Allergológiai Klinika, \\ ${ }^{2}$ Orvosi Fizikai és Orvosi Informatikai Intézet, Szeged \\ ${ }^{3}$ Békés Megyei Központi Kórház, Gyula \\ ${ }^{4}$ Magyar Tudományos Akadémia-Szegedi Tudományegyetem, Dermatológiai Kutatócsoport, Szeged
}

\begin{abstract}
Bevezetés és célkitüzés: A melanoma malignum igen agresszív, sokszor kiszámíthatatlan kórlefolyású daganat. Vizsgálatunk során arra kerestünk választ, hogy milyen tényezők befolyásolják a betegség korai felismerését. Módszer: 139 melanomával diagnosztizált beteg kérdőíveit elemeztük. Eredmények: Megállapítottuk, hogy betegeink a cardiovascularis betegségek terén egészségtudatosak, daganatok miatt végzett szürővizsgálatokon behívásra részt vesznek, azonban melanomával kapcsolatos ismereteik hiányosak. Önvizsgálatot a betegek nagy része végez, de nem tudják mit kell figyelni a bőrön. A melanomát általában maguk a betegek észlelik először, azonban sokszor több mint egy év telik el, míg orvoshoz fordulnak. A korai felismerést egyértelműen befolyásoló tényezóként a betegek attitűdjét azonosítottuk. Akik számára fontos a gyanús bőrelváltozások figyelése, azoknál korai stádiumban kerül felismerésre a melanoma. Megállapítottuk továbbá, hogy a betegek levetkőztetése és a bőrrák prevenciójával kapcsolatos kommunikáció nem része a rutin egészségügyi ellátásnak. Következtetések: Fontos a népesség és az egészségügyi személyzet melanomával kapcsolatos ismereteinek bővítése és annak a tudatosítása, hogy a korai felismerés életet menthet.
\end{abstract}

Kulcsszavak: melanoma malignum, korai felismerés, prevenció

\section{Factors influencing early detection of malignant melanoma}

Introduction and aim: Melanoma is a highly aggressive tumour with often unpredictable outcome. Our aim with this study was to determine factors influencing early detection of melanoma. Method: We analyzed 139 questionnaires completed by patients diagnosed with melanoma. Results: We found that our patients are health-conscious regarding cardiovascular diseases and attend cancer screenings on recall. However, their knowledge about melanoma is insufficient. Most of them perform skin self-examination, but they do not know what to check. Melanoma is detected mostly by the patients themselves, but it takes more than one year to consult a doctor. Our study confirmed that patients' attitude toward melanoma is an important factor influencing early detection. We found that physical examination and communication about skin cancer prevention is not part of the routine medical care. Conclusions: It is important to improve knowledge about melanoma among the general population and health care providers and to emphasize that early detection can save lives.

Keywords: malignant melanoma, early diagnosis, prevention

Petrovszky, I., Csányi, I., Szücs, M., Ócsai, H., Houshmand, N., Kemény, L., Oláh, J., Baltás, E. [Factors influencing early detection of malignant melanoma]. Orv. Hetil., 2016, 157(51), 2028-2033.

(Beérkezett: 2016. szeptember 11.; elfogadva: 2016. október 16.)

\section{Rövidítések}

ALM = acrolentiginosus melanoma; $\mathrm{LM}=$ lentigo maligna; LMM = lentigo maligna melanoma; NMM = nodularis melanoma; SSM = superficialisan terjedő melanoma
A melanoma malignum incidenciája az elmúlt néhány évtizedben növekedést mutatott világszerte, így hazánkban is [1-4]. Prognózisával kapcsolatosan számos irodalmi adat áll rendelkezésre, azonban a betegség kórlefolyá- 
sa sokszor kiszámíthatatlan. A korai felismerés - amelyhez gyakran elegendő egy alapos fizikális vizsgálat - életet menthet.

A melanoma korai felismerésének jelentőségét hangsúlyozzák a túlélési adatok is, amelyek szerint korai stádiumban az ötéves túlélés 98,3\%, lokoregionális áttét esetén 62,4\%, míg távoli áttét esetén csupán 16\% [5].

Korábbi kérdőíves vizsgálatok a melanoma korai felismerését befolyásoló tényezőként azonosították a női nemet, a fiatalabb életkort, a magasabb iskolai végzettséget, a kedvezóbb társadalmi-gazdasági helyzetet, a speciális egészségügyi ellátáshoz való hozzáférést, a rendszeres orvosi és önvizsgálatot, a folyamatosan fejlödő diagnosztikai eszközök használatát és a nagyszámú, atípusos anyajegy jelenlétét a bőrön [6-15].

Irodalmi adatok alapján leggyakrabban először a beteg fedezi fel melanomáját, ami hangsúlyozza az önvizsgálat jelentőségét [16]. Robinson és mtsai szerint az önvizsgálat végzését befolyásolja az egyén betegséghez való hozzáállása (attitűd), a melanomával kapcsolatos ismeretei, az életkora, valamint a kockázati tényezők ismerete [17]. A populációs szintű szürővizsgálatok korai felismerésben betöltött szerepéről megoszlanak a vélemények az irodalomban melanoma vonatkozásában. Bizonyosnak tűnik azonban, hogy a magas rizikójú csoportokat mindenképpen érdemes lenne rendszeresen szürni. A dermatoszkópia nélkülözhetetlen a bőrelváltozások diagnosztikájában és a korai felismerésben. A digitális dermatoszkópia során rögzített fénykép lehetőséget teremt a gyanús bőrlaesiók követésére és online konzultációra (teledermatoszkópia). Hazánkban is elérhető módszer a konfokális mikroszkópia, amely egy olyan noninvazív vizsgálat, melynek során in vivo sejtszinten analizálhatjuk a bőrelváltozásokat (1. ábra) [18].

\section{Módszer}

Munkánk során célul tüztük ki, hogy meghatározzuk a centrumunkban melanomával diagnosztizált betegeink körében a korai felismerést befolyásoló tényezőket. Szerettünk volna átfogó képet kapni betegeink melanomával kapcsolatos ismereteiről, attitűdjéről és a daganat felfedezésének körülményeiről.

A vizsgálat során a Susan M. Swetter és mtsai által megszerkesztett kérdőívet használtuk, amellyel korábban az Amerikai Egyesült Államokban és Görögországban történtek felmérések [19,20]. A kérdőív tíz témakörre bontható és összesen 74 kérdést tartalmaz. A felmérést a Szegedi Tudományegyetem Bőrgyógyászati és Allergológiai Klinikáján, 2015. január és október között végeztük. A felmérésbe melanomával újonnan diagnosztizált 18 év feletti betegeket vontunk be. Törekedtünk arra, hogy a kérdőív kitöltése a szövettani diagnózis közlését követő egy hónapon belül történjen. A betegeket három különböző csoportba soroltuk a tumorvastagság alapján (in situ, $\leq 1 \mathrm{~mm},>1 \mathrm{~mm}$ ). Korai felismerésnek tekintettük, ha felfedezéskor a primer tumor Breslow-féle abszolút tumorvastagsága nem haladta meg az $1 \mathrm{~mm}$-t, valamint nem volt lokoregionális és/vagy távoli áttét. A korai felismerést befolyásoló lehetséges paraméterek tekintetében a csoportok közötti összehasonlításhoz $\chi^{2}$-próbát, Fisher-féle egzakt tesztet, valamint Spearman-féle korrelációanalízist használtunk. A statisztikai próbákat az $\mathrm{R}$ statisztikai programmal végeztük $(\mathrm{p}<0,05)$. Eredményeinket a kérdőívvel korábban készült amerikai és görög tanulmánnyal összevetve is elemeztük.

\section{Eredmények}

Összesen 153 beteg töltötte ki a kérdőívet, amelyből 139-et találtunk alkalmasnak a statisztikai elemzésre. Demográfiai adatok tekintetében (1. táblázat) betegeink átlagéletkora 59 év (22-93 év) volt. A három tumorvastagság szerinti csoport között különbséget átlagéletkor vonatkozásában nem találtunk (in situ: 57,3 év, s1 mm: 57,8 év, >1 mm: 62,5 év). Betegeink 12\%-a 40 éves kor alatti, 40\%-a 40 és 60 éves kor közötti, 48\%-a 60 év feletti volt. Az $1 \mathrm{~mm}$-nél vastagabb melanomával diagnosztizált betegek 63\%-a 60 év feletti volt. A nemenkénti megoszlás közel azonosnak bizonyult (70 férfi, 69 nő). A válaszadók 19\%-a alapfokú, 31\%-a szakmunkás, 27\%-a középfokú, 23\%-a felsőfokú végzettséggel rendelkezett.

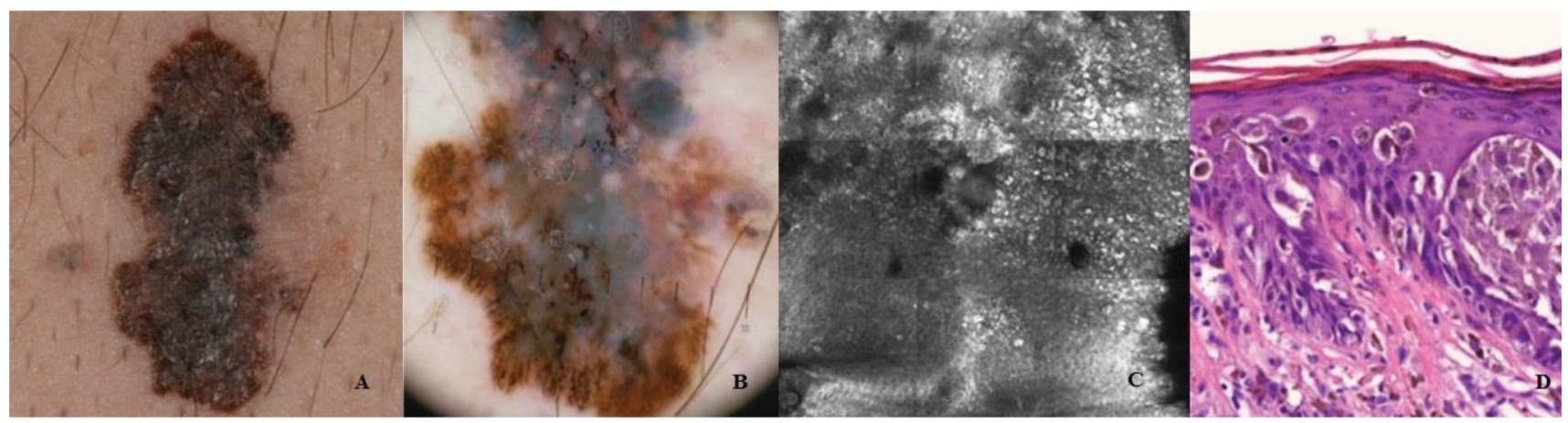


1. táblázat | Betegeink demográfiai jellemzői $(\mathrm{n}=139)$

\begin{tabular}{lll}
\hline Átlagéletkor (év) & 59 év (22-93 év) & \\
\hline Korcsoportok $(\%$, fö) & $<40$ év & $12 \%(16)$ \\
& $40-60$ év & $40 \%(56)$ \\
& $>60$ év & $48 \%(67)$ \\
\hline Nem $(\%$, fö $)$ & Férfi & $50 \%(70)$ \\
\hline Iskolai végzettség (\%, fö) & Nlapfokú & $50 \%(69)$ \\
& Szakmunkás & $31 \%(43)$ \\
& Középfokú & $27 \%(38)$ \\
Bőrtípus $(\%$, fó) & Felsőfokú & $23 \%(32)$ \\
\hline
\end{tabular}

2. táblázat $\mid$ A primer melanoma paraméterei $(\mathrm{n}=139)$

\begin{tabular}{lll}
\hline $\begin{array}{l}\text { Breslow-féle átlagos } \\
\text { tumorvastagság }(\mathrm{mm})\end{array}$ & $1,645 \mathrm{~mm}(0,152-17,024 \mathrm{~mm})$ \\
\hline $\begin{array}{l}\text { Tumorvastagság szerinti } \\
\text { három csoport }(\%, \mathrm{db})\end{array}$ & In situ & $19 \%(26)$ \\
& $\leq 1 \mathrm{~mm}$ & $44 \%(62)$ \\
\hline Lokalizáció $(\%, \mathrm{db})$ & Törzs & $37 \%(51)$ \\
\hline Alsó végtag & $53 \%(73)$ \\
& Fej-nyak & $15 \%(21)$ \\
\hline Szövettani típus $(\%, \mathrm{db})$ & Felsó végtag & $12 \%(17)$ \\
& SSM & $69 \%(96)$ \\
& NMM & $16 \%(23)$ \\
\hline ulcervettanilag igazolt & LMM & $6 \%(9)$ \\
\hline db) & ALM & $4 \%(5)$ \\
& LM & $14 \%(1)$ \\
& Egyéb & $45)$ \\
\hline
\end{tabular}

A primer tumor jellemzői (2. táblázat) tekintetében az eltávolított melanomák Breslow-féle átlagos tumorvastagsága 1,645 mm volt. A betegek 19\%-ánál diagnosztizáltunk in situ, 44\%-ánál 1 mm-nél vékonyabb és 37\%-ánál 1 mm-nél vastagabb melanomát. A szövettani típus tekintetében az összes eset 69\%-a superficialisan terjedő melanoma (SSM), 16\%-a nodularis melanoma (NMM), 6\%-a lentigo maligna melanoma (LMM), 4\%-a acrolentiginosus melanoma (ALM) és 1\%-a lentigo maligna (LM) volt. A vékony melanomák között leggyakoribb az SSM volt, míg az 1 mm fölötti csoportban közel azonos gyakoriságú volt az SSM és az NMM. Összesen 20 tumor (14\%) volt szövettanilag ulcerált, amelyből 15 esetben (75\%) 1 mmnél vastagabb volt a daganat. A primer daganatok lokalizációját tekintve a leggyakoribb lokalizáció a törzs (53\%) volt, amelyet az alsó végtagi (20\%), a fej-nyaki (15\%) és a felső végtagi (12\%) régió követett. Az 1 mm-nél vastagabb tumorok esetében a törzs (45\%) és az alsó végtag (31\%) bizonyultak a leggyakoribb lokalizációnak.

Az egészségügyi és prevenciós szokások terén (3. táblázat) felmértük, hogy betegeink mennyire egészségtudatosak. Nőbetegeink 71\%-a vett részt korábban mammográfiás vizsgálaton és 77\%-a méhnyakrákszürésen. A férfi válaszadóink 30\%-a járt prosztatarákszürésen. Mindkét nemet figyelembe véve vastagbéltükrözésen a részvételi arány $20 \%$ volt. A kérdőíves vizsgálatot megelőző évre rákérdezve a vérnyomásértékével válaszadóink 94\%-a, a koleszterinértékével 70\%-a volt tisztában. Fényvédelem céljából betegeink mindössze 27\%-a használt rendszeresen fényvédő készítményt, valamint 23\%-a viselt széles karimájú kalapot, 28\%-a hosszú ujjú inget vagy pólót.

Megkérdeztük betegeinket a rendszeres önvizsgálat végzéséról és alaposságáról. Az alaposságot illetően a testfelszín 13 régiójából kellett kiválasztani, hogy melyeket figyelték. Míg a 139 betegből 49-en (35\%) egyáltalán nem ellenőrizték a bőrüket, addig a válaszadók közel fele hatnál több testtájat vizsgált. Az önvizsgálat végzése és alapossága vonatkozásában a három különböző tumorvastagságú csoport között szignifikáns különbséget nem találtunk ( $p>0,05)$. Amikor a bőrüket ellenőrizték, 139 betegből csupán hatan (4\%) jelezték, hogy tájékozódtak előtte melanomáról készült fotó alapján.

A partner/családtag/barát szerepe nem elhanyagolható a betegség diagnosztizálásában. A válaszadók körülbelül felének segített családtag vagy barát figyelni az anyajegyeit (46\%) és ellenőrizni a bőrét (52\%). A melanoma diagnosztizálását megelőző egy évben a válaszadók 61\%-a házas volt, 77\%-a egy háztartásban élt valakivel. Ezek a körülmények azonban nem segítették a melanoma korai felismerését $(p>0,05)$.

3. táblázat | Betegeink prevenciós szokásai és egészségtudatossága

\begin{tabular}{|c|c|}
\hline $\begin{array}{l}\text { Részt vett korábban mammográfiás szürésen } \\
(\%, \text { fö })\end{array}$ & $71 \%(49 / 69)$ \\
\hline Részt vett korábban méhnyakrákszűrésen (\%, fő) & $77 \%(53 / 69)$ \\
\hline Részt vett korábban prosztatarákszưrésen (\%, fö) & $30 \%(21 / 70)$ \\
\hline $\begin{array}{l}\text { Részt vett korábban colontumorszűrésen (mindkét } \\
\text { nem, \%, fö) }\end{array}$ & $20 \%(28 / 139)$ \\
\hline $\begin{array}{l}\text { A felmérést megelőző évben tisztában volt } \\
\text { vérnyomásértékével (\%, fő) }\end{array}$ & $94 \%(131 / 139)$ \\
\hline $\begin{array}{l}\text { A felmérést megelőző évben tisztában volt } \\
\text { koleszterinszintjével (\%, fö) }\end{array}$ & $70 \%(98 / 139)$ \\
\hline $\begin{array}{l}\text { Fényvédő készítményt rendszeresen alkalmaz } \\
(\%, \text { fó })\end{array}$ & (139) \\
\hline
\end{tabular}

Fényvédelem céljából rendszeresen használ kalapot 23\% (32/139) $(\%$, fó)

Fényvédelem céljából rendszeresen használ ruházatot $(\%$, fó) 
A betegségekkel kapcsolatos attitüd és ismeretek nagymértékben befolyásolják a betegek viselkedését betegségükkel kapcsolatosan. A melanoma diagnosztizálását megelőző egy évben válaszadóink 71\%-a úgy gondolta, hogy odafigyelt az egészségére, azonban csupán 21 -en (15\%) érdeklődtek rendszeresen a bőrrák felismerésének lehetőségeiről. Többszörös választás keretében mértük fel, hogy betegeink fontosnak tartják-e, hogy figyeljék bőrükön a melanomára utaló gyanújeleket. Míg a legvastagabb tumorokat azoknál diagnosztizáltuk, akik számára egyáltalán nem volt fontos bőrük ellenőrzése, addig azon betegeknél, akik számára fontos volt a gyanújelek észlelése, 80\%-ban in situ és $1 \mathrm{~mm}$-nél vékonyabb melanomát észleltünk $(\mathrm{p}=0,027)$. A kérdő́ivet kitöltő betegeink közel 74\%-a soha nem gondolt arra, hogy veszélyeztetett melanoma szempontjából, és mindössze 13\%-uk gondolta, hogy másokhoz képest több esélye van erre a daganattípusra. A diagnózis felállítását megelőzően betegeink 38\%-a nem tudta, hogy a melanoma egy rosszindulatú bőrdaganat. Figyelemfelkeltő, hogy a diagnózis felállítását követően betegeink 29\%-a szerint a melanoma nem súlyos megbetegedés, és $44 \%$-uk nem számít súlyos egészségügyi következményekre.

Az egészségügyi ellátás és kommunikáció korai felismerésben betöltött szerepére vonatkozóan is megkérdeztük betegeinket (4. táblázat). A melanoma diagnosztizálását megelőző évben a betegek háromnegyed része $(72 \%)$ rendszeresen járt egészségügyi szakemberhez valamilyen egészségügyi okból. A vizitek során bőrvizsgálat a betegek csupán 28\%-ánál történt (teljes: $72 \%$, részleges: $28 \%$ ), amelynek felében (54\%) az orvosi rutinvizsgálat részeként, míg 46\%-ban a beteg/hozzátartozó/barát kezdeményezésére. A válaszadók mindössze $13 \%$-a beszélgetett valaha orvosával vagy más egészségügyi szakemberrel a bőrrákról, 9\%-nak említették meg, hogy veszélyeztetett melanoma szempontjából, 8\% kapott pontos tanácsot, hogy mit és hogyan kell figyelnie a börén és $6,5 \%$ tudott atípusos anyajegyéról.

A melanoma felfedezésének körülményeit is vizsgáltuk. A melanomát az esetek 54\%-ában maga a beteg, 25\%-

4. táblázat Egészségügyi ellátás és kommunikáció a melanoma diagnosztizálását megelőző évben $(\mathrm{n}=139)$

\begin{tabular}{|c|c|}
\hline $\begin{array}{l}\text { Valamilyen egészségügyi indokkal rendszeresen járt } \\
\text { orvoshoz }(\%, \text { fó })\end{array}$ & $72 \%(100)$ \\
\hline Bőrvizsgálat történt az orvosi vizsgálat során (\%, fő) & $28 \%(39)$ \\
\hline - Teljes bőrvizsgálat & 28 fó \\
\hline - Részleges bőrvizsgálat & 11 fó \\
\hline - Rutin részeként & 21 fó \\
\hline - Beteg vagy hozzátartozó kérésére & 18 fó \\
\hline Beszélgetett orvosával a melanomáról (\%, fö) & $13 \%(18)$ \\
\hline $\begin{array}{l}\text { Figyelmeztette orvosa, hogy veszélyeztetett melanoma } \\
\text { szempontjából }(\%, \text { fó) }\end{array}$ & $9 \%(12)$ \\
\hline $\begin{array}{l}\text { Pontos tanácsot kapott, hogy mit és hogyan kell } \\
\text { figyelnie a bőrén }(\%, \text { fó })\end{array}$ & $8 \%(11)$ \\
\hline
\end{tabular}

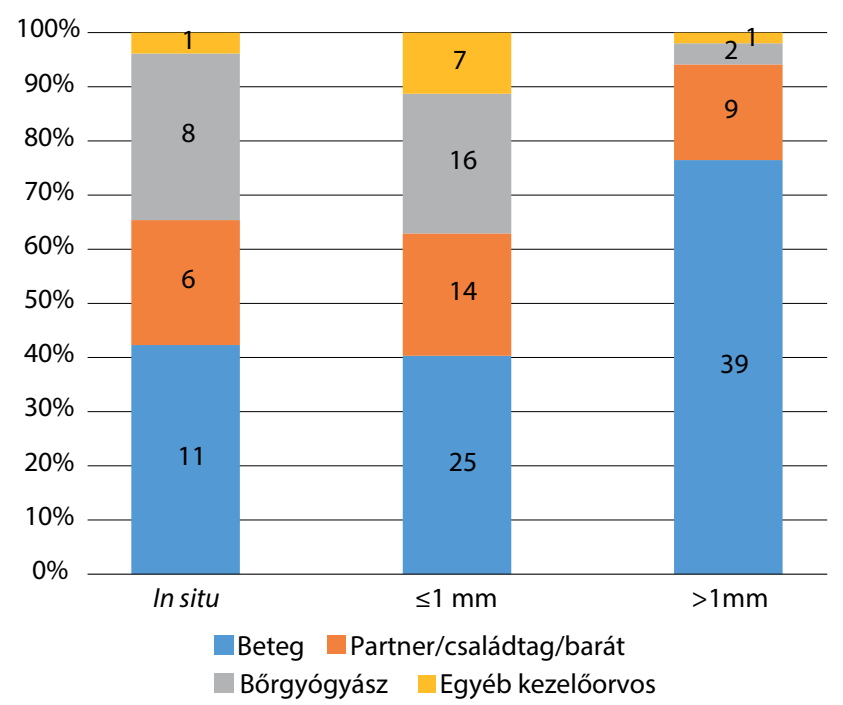

2. ábra $\mid$ A melanomának bizonyuló laesiót elsőként észlelő személy $(\%$, fó $)$

ában az orvos (18\%: bőrgyógyász, 7\%: egyéb kezelőorvos), 2l\%-ában a partner/családtag/barát észlelte elöször (2. ábra). A gyanús bőrelváltozást mindhárom tumorvastagság szerinti csoportban leggyakrabban a beteg észlelte. Az $1 \mathrm{~mm}$ feletti tumorok 94\%-át, az $1 \mathrm{~mm}$ alatti és az in situ melanomák közel 65\%-át a beteg vagy a partner/család/hozzátartozó vette észre. Az átlagos tumorvastagság a szakemberek (bőrgyógyász: 0,384 $\mathrm{mm}$, egyéb kezelóorvos: $1,003 \mathrm{~mm}$ ) által felismert laesióknál vékonyabb volt, mint a laikusoknál (hozzátartozó: $1,913 \mathrm{~mm}$, beteg: $2,048 \mathrm{~mm}$ ). A betegek leggyakrabban a gyanús bőrlaesio méretének $(50 \%)$, színének $(40 \%)$, bőrfelszínhez viszonyított előemelkedésének (33\%) változását észlelték, illetve azt, hogy „a bőrelváltozás más lett, mint korábban volt” (37\%).

A kérdő́ivet kitöltő́k 7\%-a szerint a késóbb melanomának bizonyuló bőrelváltozás mindig ott volt a bőrén, $32 \%$ egy évnél hosszabb ideje, $45 \%$ egy évnél rövidebb ideje észlelte az elváltozást, 17\% kizárólag a diagnózis felállításakor figyelt fel rá.

Arra vonatkozólag is kerestük a lehetséges okokat, hogy a betegek a gyanús laesio észlelését követően miért késlekedtek orvoshoz fordulni. A betegek közel fele (48\%) egyszerúen nem aggódott a bőrelváltozás miatt, kisebb részük az időhiányt, egyéb egészségügyi problémákat vagy munkahelyi okokat nevezett meg. Miután a betegek a gyanús laesióval egészségügyi szakemberhez fordultak, az esetek 88\%-ában körülbelül 10 nap múlva szakellátásra (bőrgyógyászati vizsgálat, sebészi eltávolítás) került sor.

\section{Megbeszélés}

A melanoma korai felfedezését befolyásoló tényezők vizsgálatát illetően számos adat áll rendelkezésre a szakirodalomban [6-15]. A Susan M. Swetter és mtsai által 
megszerkesztett kérdőívvel vizsgálatunkon kívül két tanulmány készült $[19,20]$. Az Amerikai Egyesült Államokban a kérdőívet kitöltők $61 \%$-a férfi volt, a medián tumorvastagság 1,25 mm-nek adódott, és az esetek 57\%ában $1 \mathrm{~mm}$-nél vastagabb tumort diagnosztizáltak. Vékony tumor $(\leq 1 \mathrm{~mm})$ esetében gyakoribb volt az SSM és az LMM, az ulceratio hiánya, a végtagi vagy törzsi lokalizáció, a fiatalabb életkor ( $\leq 60$ év), a nói nem, a magasabb iskolai végzettség és a valamilyen rendszerességgel végzett általános orvosi vizsgálat. Vékony melanomát azoknál diagnosztizáltak, akik végeztek önvizsgálatot, amelyhez melanomáról készült fotót használtak, és akiknek a figyelmét korábban felhívták az atípusos anyajegyeikre. A 60 évnél idősebb férfiak körében vékony tumorokat azoknál diagnosztizáltak, akiknél az általános orvosi vizsgálat során a teljes testfelületet átnézték [19].

A Görögországban elvégzett vizsgálat során azt találták, hogy a vékonyabb melanomák gyakrabban helyezkedtek el a fej-nyak és a felső végtag területén. A korai felismeréssel nem függött össze a magasabb iskolai végzettség. A vizsgálat fó megállapítása az volt, hogy a korai felismerést befolyásoló legfontosabb tényezők az önvizsgálat végzése és a családi állapot. Akik házasok voltak, azok között több mint háromszor gyakrabban fedeztek fel 1 mm-nél vékonyabb daganatot, mint azoknál, akik nem voltak házasok [20].

Centrumunkban elvégzett vizsgálatunkban az átlagéletkor, hasonlóan a nemzetközi felmérésekhez, 60 év körül mozgott (amerikai: 56 év, görög: 55 év, magyar: 59 év) $[19,20]$. Betegeink 37\%-ánál diagnosztizáltunk 1 mm-nél vastagabb melanomát. Ezeknek a betegeknek a kétharmada a 60 év feletti korcsoportba tartozott. A szövettani típusokat illetően a vékony melanomák között leggyakoribb az SSM volt, míg az $1 \mathrm{~mm}$ fölötti csoportban közel azonos gyakorisággal fordult elő SSM és NMM. Az 1 mm-nél vastagabb melanomáknál szignifikánsan több ulcerált elváltozást találtunk, ami a rossz prognózis jele. Az $1 \mathrm{~mm}$-nél vastagabb tumorok, a görögországi vizsgálat eredményéhez hasonlóan, leggyakrabban a törzsön és az alsó végtagokon helyezkedtek el [20].

Vizsgálatunk során megállapítottuk, hogy betegeink ismeretei hiányosak a melanomáról, és még a diagnózis felállítása után sem egyértelmü számukra, hogy súlyos betegségről van szó. Betegeink egészségtudatosnak vallották magukat, vérnyomásértékükkel és koleszterinszintjükkel több mint kétharmaduk tisztában volt.

Daganatos megbetegedések miatt behívásra történt szưrővizsgálatokon betegeink kétharmada járt korábban (mammográfia: 71\%, méhnyakrákszűrés: 77\%). Behívás hiányában azonban ez az arány egyharmadra csökkent (prosztata- és vastagbélrákszúrés 30\%, illetve 20\%).

Betegeink, bevallásuk szerint, odafigyelnek az egészségükre. Ennek ellentmond, hogy melanoma tekintetében 85\%-uk nem érdeklődik a felismerés lehetőségeiről, és csak egyharmaduk használ valamilyen fényvédelmet.

Az önvizsgálat vonatkozásában elmondható, hogy a betegek harmada egyáltalán nem, míg több mint fele a bőrfelület nagy részét ellenőrzi. A korábbi amerikai és görög tanulmányban a melanoma korai felismerése és a beteg által végzett önvizsgálat között összefüggést találtak [19, 20]. Ezzel ellentétben az önellenőrzés vizsgálatunk alapján nem záloga a korai felismerésnek. Az amerikai betegek 24\%-a, a görögök 22\%-a az önellenőrzés során melanomáról készült fényképet használt segítségül, míg betegeinknél ez az arány mindössze $4 \%$ volt $[19,20]$. Mindezekből arra következtetünk, hogy a betegek nagy része végez önvizsgálatot, de nem tudja, hogy mit kell figyelnie a bőrén.

A melanomának bizonyuló laesiót leggyakrabban a betegek veszik észre elöször, azonban sokszor több mint egy év telik el, míg orvoshoz fordulnak, leginkább azért, mert nem aggódnak.

A Talaganis és mtsai által készített felmérésben a betegek 70\%-a volt házas, s ez a tény összefüggésben volt a melanoma korai felismerésével [20]. Vizsgálatunkban a melanoma diagnosztizálását megelőző egy évben a betegek kétharmada volt házas és háromnegyede élt egy háztartásban valakivel, azonban ez nem befolyásolta a korai felismerést.

Az egészségügyi szakemberek vonatkozásában elgondolkodtató, hogy melanomás betegeink a diagnózis előtti évben rendszeresen részesültek egészségügyi ellátásban, de a rutinnak nem volt része a betegek levetkőztetése és a bőrrák prevenciójával kapcsolatos kommunikáció. A betegek mindössze egyharmadánál történt bőrvizsgálat, amely az esetek harmadában a problémás laesiókra korlátozódott, illetve az esetek felében a beteg vagy hozzátartozó kérésére történt.

Vizsgálatunkban az életkor, a nem, az iskolai végzettség, az önellenőrzés és az egy háztartásban való együttélés nem befolyásolták a melanoma korai felismerését. Megállapítottuk azonban, hogy akik számára fontos a melanomára utaló gyanújelek figyelése a bőrön, azoknál a melanoma korai stádiumban kerül felismerésre.

Felmérésünk eredményei alapján elmondhatjuk, hogy minden téren szükség van a prevenciós aktivitás élénkítésére. Bővítenünk kell a népesség és az egészségügyi személyzet ismereteit a melanomáról. Tudatosítanunk kell, hogy a korai felismerés - amelyhez elegendő egy fizikális vizsgálat - életet menthet. Hangsúlyoznunk kell a rendszeres bőrvizsgálat jelentőségét, önvizsgálat vagy családtag által végzett formában. Pontos útmutatást kell adnunk arra vonatkozólag, hogy mit kell figyelni a bőrön és mikor kell szakemberhez fordulni. Az egészségügyi személyzet esetén fontos elérnünk, hogy a teljes bőrvizsgálat az egészségügyi ellátás rutinrésze legyen. Kommunikáció céljából a televízió és az internet tûnnek legígéretesebbnek. 
Anyagi támogatás: A közlemény a Bolyai János Kutatási Ösztöndíj támogatásával készült.

Szerzői munkamegosztás: P. I., Ó. H., Sz. M., K. L., O. J. B. E.: Hipotézisek kidolgozása. P. I., Cs. I., Ó. H., N. H., B. E.: A vizsgálat lefolytatása. P. I., Cs. I., Sz. M., B. E.: Statisztikai elemzések. P. I., Cs. I., Ó. H., Sz. M., N. H., K. L., O. J., B. E.: A kézirat megszövegezése. A cikk végleges változatát valamennyi szerző elolvasta és jóváhagyta.

Érdekeltségek: A szerzőknek nincsenek érdekeltségeik.

\section{Köszönetnyilvánítás}

Köszönetet mondunk az 1. ábrán szereplő képekért Dr. Varga Erika adjunktusnőnek (Bőrgyógyászati Klinika, Szeged).

\section{Irodalom}

[1] Garbe, C., Leiter, U.: Melanoma epidemiology and trends. Clin. Dermatol., 2009, 27(1), 3-9.

[2] Forsea, A. M., del Marmol, V., de Vries, E., et al.: Melanoma incidence and mortality in Europe: new estimates, persistent disparities. Br. J. Dermatol., 2012, 167(5), 1124-1130.

[3] Geller, A. C., Clapp, R. W., Sober, A. J., et al.: Melanoma epidemic: an analysis of six decades of data from the Connecticut Tumor Registry. J. Clin. Oncol., 2013, 31(33), 4172-4178.

[4] National Institute of Oncology, Budapest: National Cancer Registry, 2013. [Országos Onkológiai Intézet: Nemzeti Rákregiszter, 2013.] [Hungarian]

[5] DeSantis, C. E., Lin, C. C., Mariotto, A. B., et al.: Cancer treatment and survivorship statistics, 2014. CA Cancer J. Clin., 2014 $64(4), 252-271$.

[6] Schwartz, J. L., Wang, T. S., Hamilton, T. A., et al.: Thin primary cutaneous melanoma: associated detection patterns, lesion characteristics, and patient characteristics. Cancer, 2002, 95(7), $1562-1568$

[7] Lasithiotakis, K., Leiter, U., Meier, F., et al.: Age and gender are significant independent predictors of survival in primary cutaneous melanoma. Cancer, 2008, 112(8), 1795-1804

[8] Durbec, F., Vitry, F., Granel-Brocard, F., et al.: The role of circumstances of diagnosis and access to dermatological care in early diagnosis of cutaneous melanoma: a population-based study in France. Arch. Dermatol., 2010, 146(3), 240-246.

[9] Swetter, S. M., Johnson, T. M., Miller, D. R., et al.: Melanoma in middle-aged and older men: a multi-institutional survey study of factors related to tumor thickness. Arch. Dermatol., 2009, 145(4), 397-404.

[10] Van Durme, D. J., Ferrante, J. M., Pal, N., et al.: Demographic predictors of melanoma stage at diagnosis. Arch. Fam. Med., 2000, 9(7), 606-611.

[11] Pollitt, R. A., Geller, A. C., Brooks, D. R., et al.: Efficacy of skin self-examination practices for early melanoma detection. Cancer Epidemiol. Biomarkers Prev., 2009, 18(11), 3018-3023.

[12] Feldman, S. R., Fleischer, A. B. Jr: Skin examinations and skin cancer prevention counseling by US physicians: a long way to go. J. Am. Acad. Dermatol., 2000, 43(2 Pt 1), 234-237.

[13] Epstein, D. S., Lange, J. R., Gruber, S. B., et al.: Is physician detection associated with thinner melanomas? JAMA, 1999, 281(7), 640-643

[14] Koh, H. K., Norton, L. A., Geller, A. C., et al.: Evaluation of the American Academy of Dermatology's National Skin Cancer Early Detection and Screening Program. J. Am. Acad. Dermatol., 1996, 34(6), 971-978.

[15] Stratigos, A., Nikolaou, V., Kedicoglou, S., et al.: Melanoma/skin cancer screening in a Mediterranean country: results of the Euromelanoma Screening Day Campaign in Greece. J. Eur. Acad. Dermatol. Venereol., 2007, 2l(1), 56-62.

[16] Brady, M. S., Oliveria, S. A., Christos, P. J., et al.: Patterns of detection in patients with cutaneous melanoma. Cancer, 2000, $89(2), 342-347$.

[17] Robinson, J. K., Fisher, S. G., Turrisi, R. J.: Predictors of skin selfexamination performance. Cancer, 2002, 95(1), 135-146.

[18] Terushkin, V., Halpern, A. C.: Melanoma early detection. Hematol. Oncol. Clin. North Am., 2009, 23(3), 481-500.

[19] Swetter, S. M., Pollitt, R. A., Johnson, T. M., et al.: Behavioral determinants of successful early melanoma detection: role of self and physician skin examination. Cancer, 2012, 118(15), 37253734.

[20] Talaganis, J. A., Biello, K., Plaka, M., et al.: Demographic, behavioural and physician-related determinants of early melanoma detection in a low-incidence population. Br. J. Dermatol., 2014, $171(4), 832-838$.

(Petrovszki Irén,

Gyula, Semmelweis u. 1., 5700 e-mail: petrovszki.iren@gmail.com)

Az Orvosi Hetilap egyes számai megvásárolhatók a Mediprint Orvosi Könyvesboltban.

Cím: Budapest V., Múzeum krt. 17. - Telefon: 317-4948 